\title{
Sedimentary facies, paleoenvironments and reservoir potential of the Afikpo Sandstone on Macgregor Hill area in the Afikpo Sub-basin, southeastern Nigeria
}

\author{
Anthony U. Okoro' ${ }^{1}$ Ezekiel O. Igwe ${ }^{2}$ (D) Isaac A. Umo²
}

Received: 6 March 2020 / Accepted: 28 September 2020 / Published online: 22 October 2020

(c) Springer Nature Switzerland AG 2020

\begin{abstract}
Sedimentary facies, petrographic and textural analyses of sections of the Afikpo Sandstone on Macgregor Hill area in the Afikpo Sub-basin, southeastern Nigeria, were carried out to evaluate the paleoenvironments and reservoir potential. Result of the sedimentary facies analysis revealed eight lithofacies grouped into estuarine and subtidal sand ridge/foreshore lithofacies associations. The facies include planar cross-stratified sandstone, bioturbated sandstone, trough crossstratified sandstone, parallel laminated sandstone, bioturbated cross-stratified sandstone, sandy bioturbated heterolith, conglomerate and laminated mudstone. The estuarine lithofacies associations show tripartite subdivision into a mudflat deposits, fluvio-estuarine sandstones in bayhead delta environments and central estuarine dominated by intertidal bayfill and lagoonal muddy deposits. Skolithos-Cruziana ichnogenera of high-energy shallow water were recorded in the bioturbated lithofacies. They showed moderate to high intensity of bioturbations, dominantly and intermittently distributed feeding structures. Petrography of the sandstones shows that samples from different lithofacies differ in compositions and textures. Generally, the sandstone consists of mainly quartz and subordinate weathered feldspar and metamorphic rock fragments as framework elements. The textural characteristics of the Afikpo Sandstone using univariate parameters of mean, standard deviation, skewness and kurtosis and the multivariate discriminate functions suggest the sediments were deposited in high-energy fluvio-marine setting. The sandstones showed good porosity range from 0.485 to 0.499 with an average value of 0.489 and the empirical permeability of 26.03-42.64 md with an average value of $39.86 \mathrm{md}$, which reveal the sandstones as good reservoirs indicating the Afikpo Sandstone as potential for hydrocarbon reservoir for subsurface analogue.
\end{abstract}

Keywords Sedimentary facies · Sieve analysis · Paleoenvironments $\cdot$ Reservoir potential · Afikpo Sandstone

\section{Introduction}

The Afikpo Sub-basin is part of the Anambra Basin [1]. The Campanian to Maastrichtian sedimentary succession within the sub-basin unconformably overlies preSantonian sediments of the southern Benue Trough. The
Nkporo Group, Mamu, Ajali and Nsukka formations (Fig. 1) comprise the sediment fill in the sub-basin which is partly sandwiched between the southern Benue Trough and the Niger Delta Basin [2]. The Afikpo Sandstone, a basal unit of the Nkporo Group in the sub-basin, was deposited during the late Campanian-early Maastrichtian. The Afikpo

Electronic supplementary material The online version of this article (https://doi.org/10.1007/s42452-020-03601-5) contains supplementary material, which is available to authorized users.

Ezekiel O. Igwe, ezekieloigwe@gmail.com; ezekiel.igwe@ebsu.edu.ng| 'Department of Geological Sciences, Nnamdi Azikiwe University, Awka, Nigeria. ${ }^{2}$ Department of Geology, Ebonyi State University, Abakaliki, Nigeria. 


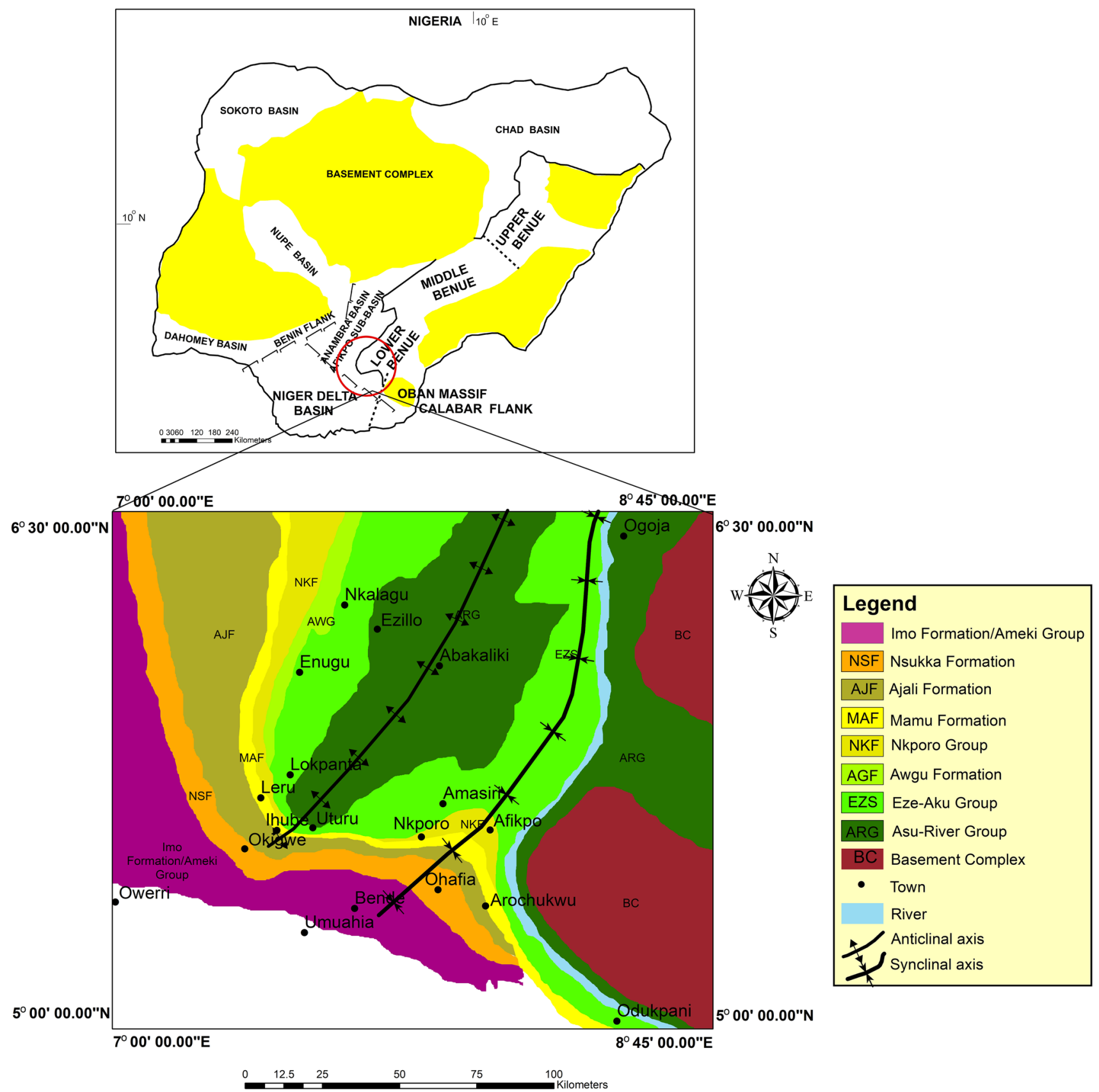

Fig. 1 Geologic map of southeastern Nigeria showing position of Nkporo Group relative to other formations (modified after [59])

Sandstone overlies the angular unconformity above the Eze-Aku Group (late Cenomanian-Turonian) facies near Ozizza and Amasiri areas. The Afikpo Sandstone comprises thick succession of cross-bedded and bioturbated sandstones, sandy heteroliths, coal stingers and muddy heteroliths. This study intends to address the problem of paleoenvironmental setting for the Afikpo Sandstone. The paleoenvironments for the Nkporo Group with Afikpo Sandstone as a formational component in the sub-basin were grossly interpreted as shallow marine and brackish water solely based on biostratigraphic evidences [3-6]. Some of the researchers noted that the Nkporo Formation consists of fossiliferous shales with shelly limestones and concretions and interpreted the depositional environment for the unit to vary from shallow marine through coast of barrier complexes to estuarine setting, while [3] and [5] interpreted the formation as shallow marine and brackish water based on fossil and palynological data.

The Afikpo Sub-basin and Anambra Basin attracted the attention of the Shell D'arcy geologists [3] who were

\section{SN Applied Sciences}


in search for oil and fossil fuels in the inland sedimentary basin of the southeastern Nigeria. Part of the outcome of the search is the discovery of smells in Nguzu and Amangwu Edda areas in the Afikpo area and oil seepage in Ugwueme and Uturu areas [7]. Discovery of oil seepages and smells in the Afikpo area led credence to further evaluate the sedimentological characteristics of the sandstone as potential reservoir facies for hydrocarbon. The depositional dynamics and energy of the environment control reservoir properties of the rocks such as the porosity and permeability. Depositional environmental setting is key to identifying depositional facies capable of storing and transmitting fluids, such as hydrocarbons. The depositional facies is derived from the vertical changes in the rock and the lateral variations across lithofacies unit which are largely controlled by factors such as depositional processes, changes in flow regimes and velocity, lithofacies changes and faults. The depositional porosity of sandstone reservoir is controlled by grain sorting and packing [8], while its permeability is controlled by grainsize variations. The purpose of this study is to carry out the sedimentary facies analysis and textural characterization of the Afikpo Sandstone in the study area in order to evaluate the paleoenvironments and reservoir potential.

\section{Physiography and geology}

The study area has a generally undulating topography characterized by highlands and low-lying plains. The highlands are made up of resistant sandstone ridges and the low-lying plains which represent shales. The highest relief in the study area is around the Ozizza area. The study area is made up of an interconnected network of steams which are structurally controlled. The streams exhibit dominantly dendritic pattern and are influenced by factors such as differential hardness of rocks which is reflected by their response to weathering and erosion.
The Afikpo Sub-basin is part of the Anambra Basin of southern Nigeria which subsided after the Santonian-Campanian thermo-tectonic event that folded and uplifted the Albian-Coniacian sediments of Benue Trough $[1,10]$. Murat $[10]$ proposed three major tectonic phases that took place in Albian-Santonian, Campanian-Eocene and late Paleocene-Pliocene. He noted that the three tectonic phases comprise the Abakaliki-Benue phase (Albian-Santonian), the Anambra-Benin (Campanian-mid-Eocene) and the Niger Delta phase (late Paleocene-Pliocene). These major tectonic phases resulted in the formation and subsequent reconfiguration of the southern Benue Trough. Regional Santonian compression deformed the Benue Trough inverting the main depocenter of the Abakaliki Trough and subsequently created the Anambra Basin and Afikpo Sub-basin to the northwestern and southeastern flanks of the Abakaliki Anticlinorium, respectively [10]. The sub-basin is characterized by the sediments of second sedimentary phase during late Campanian to early Paleocene in the depositional basin of southern Nigeria [11]. The sedimentary phase was initiated by the Santonian folding and uplift of the Abakaliki Anticlinorium along northeast-southwest axis [10], and the consequent dislocation of the depocenter into the Afikpo Synclinorium along the southeastern portion [10]. This resulted in a sedimentary succession comprising Nkporo Group, Mamu, Ajali and Nsukka formations. The Afikpo Sandstone which unconformably overlies Amasiri Sandstone (Eze-Aku Group) of the southern Benue Trough is overlain by shale facies of the Nkporo Group in the sub-basin. [1] noted that the unconformity is responsible for the absence of Coniacian unit in the sub-basin. The sub-basin comprises triangular-shaped embayment, covering about $1000 \mathrm{~km}^{2}$ and having total sedimentary thickness of about $3 \mathrm{~km}^{2}$. The Afikpo Sandstone is the oldest lithostratigraphic unit in the Afikpo Sub-basin (Table 1).
Table 1 Lithostratigraphic sequence for the Afikpo Subbasin of southeastern Nigeria [9]

\begin{tabular}{|c|c|c|c|}
\hline \multirow[t]{2}{*}{ Age } & \multicolumn{2}{|l|}{ Lithostratigraphic unit } & \multirow[t]{2}{*}{ Basin } \\
\hline & Formation & Subunits & \\
\hline Upper Maastrichtian & Nsukka Formation & & Afikpo Sub-basin \\
\hline \multirow[t]{2}{*}{ Middle Maastrichtian } & Ajali Formation & & \\
\hline & Mamu Formation & & \\
\hline Lower Maastrichtian & Nkporo Formation & $\begin{array}{l}\text { Amaiyi Shale, Owutu } \\
\text { Sandstone, Asaga } \\
\text { Shale }\end{array}$ & \\
\hline Campanian & $\begin{array}{l}\text { Afikpo } \\
\text { Sandstone }\end{array}$ & & \\
\hline Santonian & Angular unconformity & & Southern Benue \\
\hline Turonian & Eze-Aku Group & $\begin{array}{l}\text { Amasiri Sandstone, } \\
\text { Eze-Aku Shale }\end{array}$ & Trough \\
\hline
\end{tabular}




\section{Materials and methods}

\subsection{Field mapping}

The field mapping exercise was carried out by locating and describing exposed outcrops of the Afikpo Sandstone in the study area (Fig. 2). Transverses were made along various localities in the area. Five outcrops of the Afikpo Sandstone were studied using descriptive and lithological characteristics of the rocks. The sedimentary attributes studied include lithology, texture, sedimentary structures and contact types. The lithofacies were recognized based on these attributes. The strike and dips of the beds were measured and plotted on the maps. Eleven representative sandstone samples were collected for sieve analysis. A vertical profile of the Macgregor Hill and Ndibe section of the Afikpo Sandstone was produced. Photographs of important geologic features were also taken.

\subsection{Petrographic analysis}

Eleven thin sections were prepared from representative sandstone samples collected from the different facies of the Afikpo Sandstone on the Macgregor Hill. All the samples were friable to poorly consolidated. Therefore, they were impregnated with low-viscosity epoxy resin (lakeside cement) and baked on a glass slide of dimensions $27 \mathrm{~mm} \times 46 \mathrm{~mm}$ in size. The impregnated rock samples were allowed to harden on the slide before they were ground down to a thickness of $0.03 \mathrm{~mm}$ on a precision diamond lap plate or wheels using corundum powder. The polished thin-section surface was then covered with a thin glass cover slip to improve optical continuity with the rock. The thin-section study was done using a petrographic microscope with both incident and transmitted light capabilities. Modal analysis was done by point counting after [12] and [13]. Quantitative petrographic analysis was carried out on thin sections after the method of [14] to characterize detrital modes. Two hundred points were counted using the grid line method to evaluate the framework grain mineralogy, cement and matrix and voids (porosity).

\subsection{Sieve analysis}

The sieve analysis method was employed to determine the textural characteristics of the sandstones. The samples were sieved using the standard procedure. Eleven samples were sieved using a mechanical sieve shaker and ASTM standard arranged in a nest of $1 / 2$ phi intervals, and shaking was done for $15 \mathrm{~min}$ for each sample. An electronic weighing balance was used to weigh out $50 \mathrm{gms}$ of each sample before sieving. The weight retained in each sieve is recorded, and the cumulative weight and weight percentage are calculated. These are used to plot cumulative frequency graphs (see supplementary data, A-K) with critical percentile values for $\Phi 5, \Phi 16, \Phi 25, \Phi 50, \Phi 75, \Phi 84, \Phi 95$ and $d_{60}$ and $d_{10}$ are determined (see supplementary data, $\mathrm{L}-\mathrm{U})$, respectively. Statistics of the grain-size distribution were calculated with a geological grain-size program and grain frequency graphs. Grain-size statistical parameters and graphic representations are given in phi units. Parameters calculated in the sieve analysis are median, mean, standard deviation, skewness and kurtosis and $d_{60}$ and $d_{10}$ which are useful in the calculation of porosity and permeability of the sandstones. The median corresponds to the 50 percentile on a cumulative curve, where half the grain sizes (particles) by weight are larger and half are smaller than the median. This parameter is measured in phi units. Critical percentile values $\Phi 5, \Phi 16, \Phi 25, \Phi 50, \Phi 75, \Phi 84$ and $\Phi 95$ were obtained and used to calculate the inclusive graphic statistical parameters for each sample. These calculations were based on formulae proposed by [15], and their results and interpretations are presented.

\subsection{Evaluation of reservoir parameters}

Porosity and permeability of the sandstone unit were evaluated using the textural parameters from sieve analysis and empirical equations of 1 and 2 [16].

Porosity $=0.255\left(1+0.83^{u}\right)$.

The empirical formula for porosity used in this study is (1) equation estimated using the 10th and 60th percentile value $\left(d_{10}\right.$ and $\left.d_{60}\right)$ from grain-size distribution curve plotted in millimeter $(\mathrm{mm})$ against cumulative weight in (\%). Here, $U$ is the coefficient of uniformity represented by ratio of $\frac{d 60}{d 10}$, where $d_{60}=$ grain size at 60th percentile and $d_{10}=$ grain size at 10 th percentile. Permeability was calculated using Krumbein and Monk (1945) equation given as [17]:

$k K=g / v .6 \times 10^{-4}[1+10(n-0.26)] d_{10}^{2}$

where $k=$ hydraulic conductivity/permeability, $g=$ acceleration due to gravity, $d_{10}=$ effective grain diameter at 10th percentile [17] and [16], $v=$ kinematic viscosity at given temperature of $25^{\circ} \mathrm{C}$ and $n=$ porosity. This formula uses kinematic viscosity $(v)$ of $8.931^{*} 10^{-7}$ at temperature of $25^{\circ} \mathrm{C}$ and acceleration due to gravity $(\mathrm{g})$ of $9.8 \mathrm{~m} / \mathrm{s}^{2}$. The classification range for evaluation of porosity and permeability of [16] and [17] is shown in Table 2.

Table 2 Classification range for evaluation of porosity and permeability $[16,17]$ 


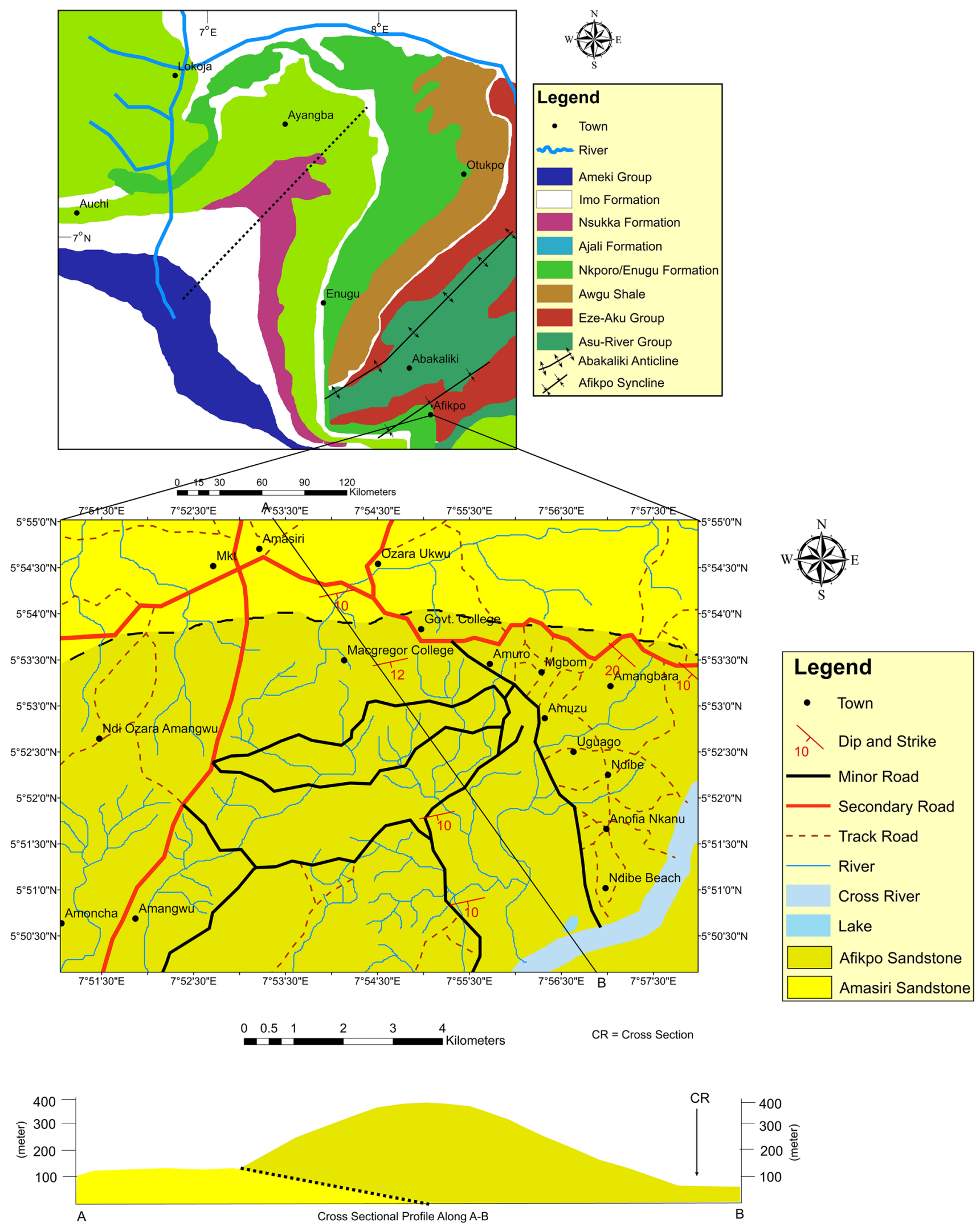

Fig. 2 Geological map of study area located inside geologic map of southeastern Nigeria 
Table 2 Classification range for evaluation of porosity and permeability (1) and (2)

\begin{tabular}{llll}
\hline Porosity $\Phi$ & Interpretation & Permeability $(\mathrm{md})$ & Interpretation \\
\hline 0.5 & Negligible & $<10-15$ & Poor-fair \\
$5-10$ & Poor & $15-50$ & Moderate \\
$15-20$ & Good & $50-250$ & Good \\
$>20-25$ & Very good & $250-1000$ & Very good \\
$>25-30$ & Excellent & $>1000$ & Excellent \\
\hline
\end{tabular}

\subsection{Multivariate and bivariate scatter analysis}

The multivariate discriminate functions $\left(y_{1}, y_{2}, y_{3}\right)$, proposed by $[17,18]$, were used for calculating inclusive graphic measure statistical grain-size data parameters of $\mathrm{mz}, \varphi$, sk and $\mathrm{kg}$ as useful environmental indicators of the Afikpo Sandstone. It has a potential to improve the success rate and refinement of the discriminate method in relation to depositional environment. The following discriminate functions were used in the present work: (1) For the discrimination between eolian processes and littoral (intertidal zone) environments, the following equation was used. $y_{1}=-3.5688 \mathrm{Mz}+3.7016 \delta^{2}-2.0766 \mathrm{SK}+3.1135 \mathrm{KG}$ [18]. $\mathrm{Mz}$ is the grain-size mean, $\delta$ is the inclusive graphic standard deviation (sorting), SK is the skewness, and $K G$ is the graphic kurtosis. When $y_{1}$ is less than -2.7411 , eolian deposition is indicated, whereas if it is greater than -2.7411 , a beach environment is suggested. (2) For the discrimination between beach (back-shore) and shallow agitated marine environments (subtidal environment), the following equation was used. $y_{2}=16.6534 \mathrm{Mz}+65.7091$ $\delta^{2}+18.1071 S K+18.5043$ KG [18]. If the value of $y_{2}$ is less than 65.3650, beach deposition is suggested, whereas if it is greater than 65.3650, a shallow agitated marine environment is likely. (3) For the discrimination between shallow marine and the fluvial environments, the following equation was used. $y_{3}=0.2852 \mathrm{Mz}-8.7604 \delta^{2}-$ $4.8932 \mathrm{SK}+0.0482 \mathrm{KG}$ [18]. If $y_{3}<-7.419$, the sample is identified as a fluvial (deltaic) deposit, and if greater than -7.419 , the sample is identified as a shallow marine deposit.

\section{Results and interpretation}

\subsection{Sedimentary facies}

Eight lithofacies were identified in this study (Figs. 3, 4 and 5). These are planar cross-stratified sandstone lithofacies (Sxp), bioturbated sandstone lithofacies (Sfb), trough cross-stratified sandstone lithofacies (Sxt), bioturbated cross-stratified sandstone lithofacies ( $\mathrm{Sxb}$ ), sandy heterolith lithofacies (Shl), conglomerate lithofacies (Cgx), laminated claystone lithofacies (Csl) and parallel laminated sandstone facies (Spl). These lithofacies are described as follows:

\subsection{Planar cross-stratified sandstone lithofacies (Sxp)}

This lithofacies consist of fine-coarse-grained sandstone but dominantly coarse grained with dispersed pebbles and planar cross-beddings (Fig. 5a). This facies exhibits moderate to poor sorting with angular to sub-rounded grains. The sandstones are poorly sorted with local admixed clay clasts and. The bed thicknesses range from 0.5 to $1.0 \mathrm{~m}$. The beddings have sharp or gradational contact with overlying and underlying facies, depending on the association. The foreset bed is graded. The planar foresets may vary from low angle $\left(8^{\circ}\right)$ to moderately high angle $\left(22-28^{\circ}\right)$ and may be rippled or contorted. This lithofacies occurs in Macgregor Hill, Ndibe Beach road and Ozizza.

\subsection{Bioturbated sandstone lithofacies (Sfb)}

This lithofacies is characterized by low diversity, but moderate to high intensity of bioturbation. The suite of burrows which include Ophiomorpha, Planolites (Fig. 5b) and Chondrites burrows were noted in the bioturbated sandstone facies on the Macgregor Hill. This lithofacies is very fine to fine grained, sometimes with large nodules and shell harsh. The sedimentary structures are absent or distorted, possibly due to bioturbation and burrowing which may have destroyed the structures. They are light gray to light brown to brown in color.

\subsection{Trough cross-stratified sandstone lithofacies (Sxt)}

This lithofacies consists of medium- to very coarse-grained sandstones with cross-stratifications (Fig. 5c). It is poorly sorted and weakly cemented with graded foreset laminae and quartz pebbles. It is characteristically trough crossstratified and shows mainly fining upward profiles. The base is sharp or scoured and erosive and often lined with lag gravel/pebbles of vein quartz and clay chips. This was observed on the Macgregor Hill near the Old entrance into the Macgregor College.

\subsection{Bioturbated cross-stratified sandstone lithofacies (Sxb)}

This lithofacies contains burrows of Ophiomorpha and Skolithos ichnospecies as well as cross-stratified bedsets (Fig. 5d). This lithofacies is medium to coarse grained, 


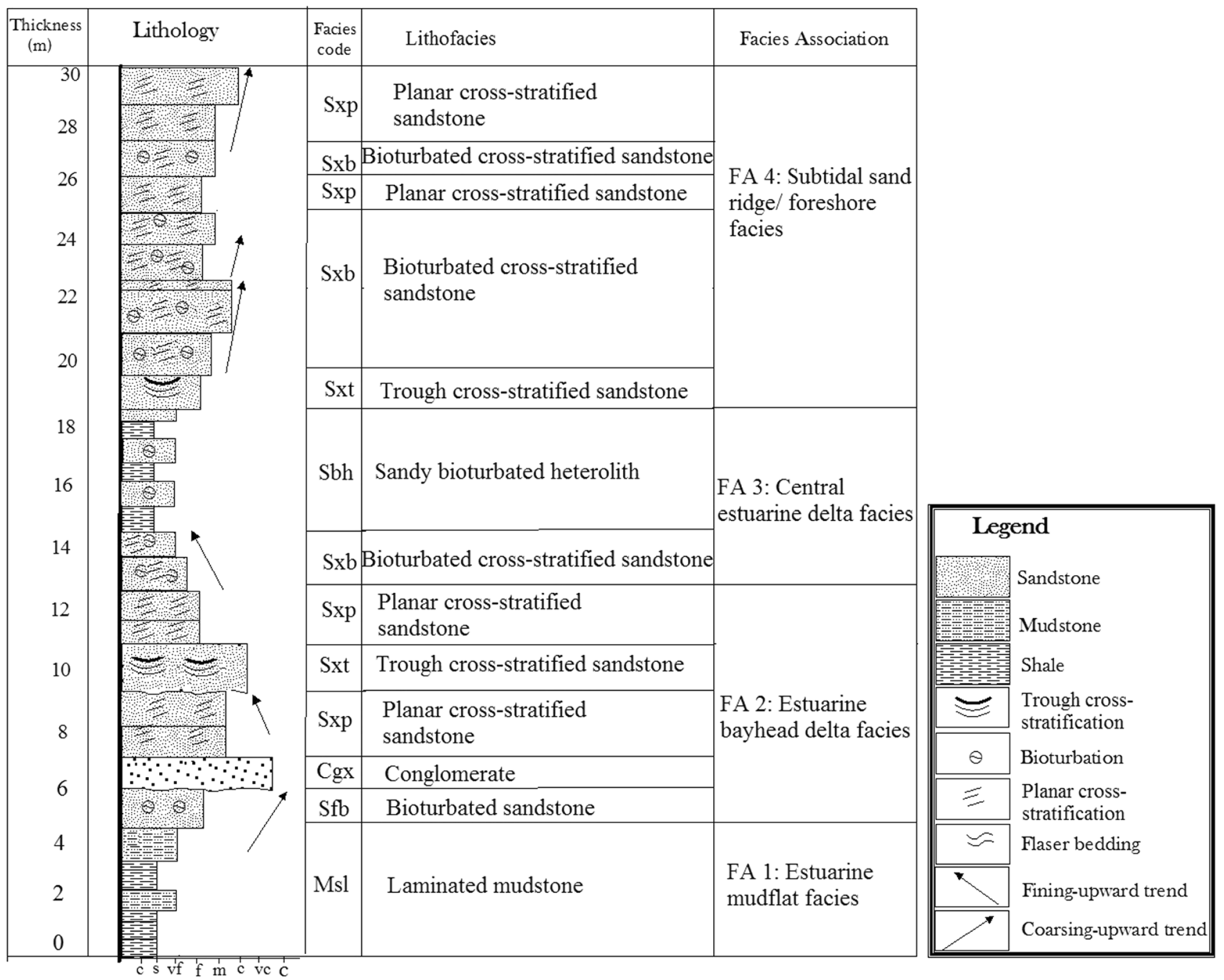

Fig. 3 Vertical profile of the Afikpo Sandstone at Macgregor Hill, Afikpo. The section indicates the identified lithofacies and facies associations (see results and discussion in the text for lithofacies descriptions as well as interpretation of depositional environments)

poorly sorted with abundant clay matrix, planar crossstratifications, occasional herringbone structures and ripples (Fig. 5e). The planar cross-stratifications occasionally show bipolar orientation of foresets beds/laminations. The Ophiomorpha isp burrows which in some places crisscross the beds in different orientations range from vertical to sub-horizontal with lengths from 7 to $35 \mathrm{~cm}$ and diameter of 1.2-2.4 cm. Ripple bedforms and megaripples exhibiting symmetrical geometry are common in the outcrop within the premises of Ebonyi Hotel premises and near the old gate to Macgregor College.

\subsection{Sandy heterolith lithofacies (Shl)}

This facies comprises very fine to grained sandstone, interbedded laminated mudstone and siltstone (Fig. 5f). The beds vary from brownish to dirty white in color. This facies is characterized by wavy ripple laminations, flaser beddings and mud layers. Horizontal burrows such as Planolites and Chondrites occur locally in this facies with moderate intensity of bioturbation. The beds thickness is range from 30 to $80 \mathrm{~cm}$. Shell fragments (bivalves and gastropod shells) and plant rootlets occur within this lithofacies.

\subsubsection{Conglomerate lithofacies (Cgx)}

This consists of conglomerates with vein quartz pebbles (Fig. $5 \mathrm{~g}$ ). The lithofacies marks the basal unconformable contact of the Afikpo Sandstone overlying the Amasiri Sandstone. This was noted on the road cut on the Macgregor Hill and along the Amasiri-Owutu Edda road. It is interpreted as basal lag of erosive-based sandstone of the fining upward motifs of the fluvial channel deposits. 


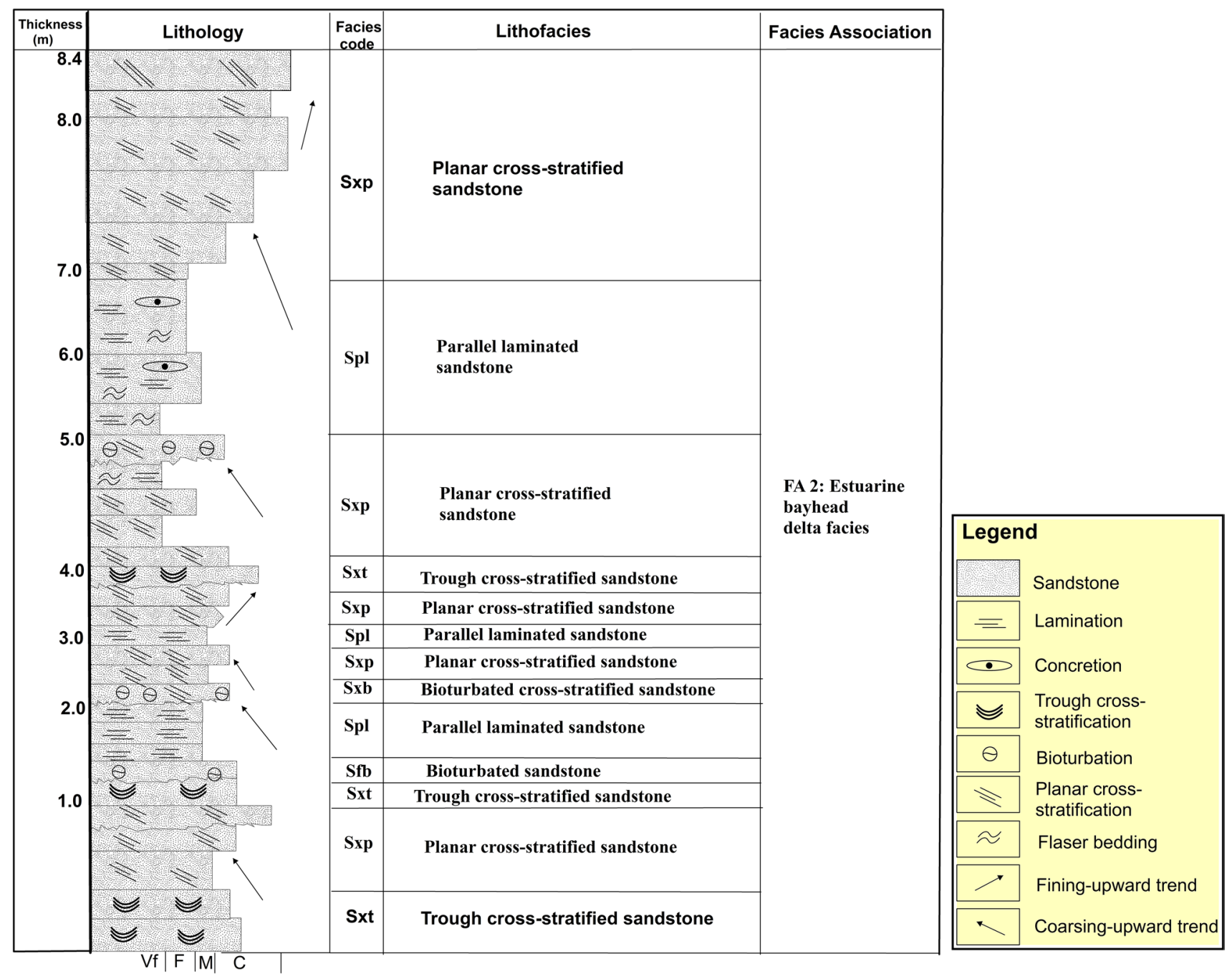

Fig. 4 Vertical profile of the Afikpo Sandstone at Amangbala-Ndibe axis, Afikpo. The section indicates the identified lithofacies and facies associations (see results and discussion in the text for lithofacies descriptions as well as interpretation of depositional environments)

\subsubsection{Laminated mudstone lithofacies (Msl)}

This consists of mudstones with occasional mm-cm-scale parallel laminations (Fig. 5h). The color of the mudstones varies from light gray or dirty white to gray or reddish brown. The interbedding muddy shales are dark gray (Fig. 5h). This lithofacies consists of body fossils such as bivalves, and contains plant/organic materials. The bed thicknesses vary from $0.15 \mathrm{~m}$ to $0.60 \mathrm{~m}$. They display low bioturbation with concretions/nodules scattered within it.

\subsubsection{Parallel laminated sandstone facies (Spl)}

This lithofacies consists of 10- to 50-cm-thick, poorly laminated, sometimes massive, silty to very fine-grained sandstones (Fig. 5i). The laminations are essentially horizontal to subhorizontal, discontinuous to continuous, $\mathrm{mm}$-scale mudstone laminations. Occasionally, these laminations are clay draped. This lithofacies in some places occurs in association with the cross-stratified lithofacies. The poor laminations may be due to reworking by wave/tides or burrowing by organisms. Bioturbations, large oval to ellipsoidal concretions and plant rootlets are common.

\subsection{Lithofacies Association}

Lithofacies is a body of rock showing lateral variations in the aspects of defined lithological characteristics [19]. Thus, facies association is derived from vertical and lateral characteristics of group of facies, nature of bedding contacts with adjacent units and erosion surfaces. In order to achieve simplicity, objectivity, repeatability and comprehensiveness, the eight identified lithofacies (Figs. 3, 4 and 5) were grouped into four main facies associations 
Fig. 5 Field photographs of sedimentary facies identified in the Afikpo Sandstone a Planar cross-stratified sandstone facies (Sxp) in the Macgregor Hill; $\mathbf{b}$ bioturbated sandstone facies in the sandstone outcrop opposite Ebonyi Hotel, Afikpo (Sfb); $c$ trough cross-stratified sandstone facies (Sxt); (d) bioturbated cross-stratified sandstone facies $(\mathrm{Sxb})$ opposite Macgregor Hill block industry, Afikpo; e ripples at the sandstone outcrop inside Ebonyi Hotel premises, Afikpo; $\mathbf{f}$ sandy bioturbated heterolith facies behind Motor Mechanic arena, Afikpo (Sbh); g conglomerate lithofacies (Cgx) in the sandstone outcrop, $200 \mathrm{~m}$ from the Macgregor College gate; $\boldsymbol{h}$ laminated mudstone lithofacies (Msl) in the sandstone outcrop along Government College axis of the Afikpo-Ozizza road; i parallel laminated sandstone facies (Spl) at Mechanic village area, Afikpo
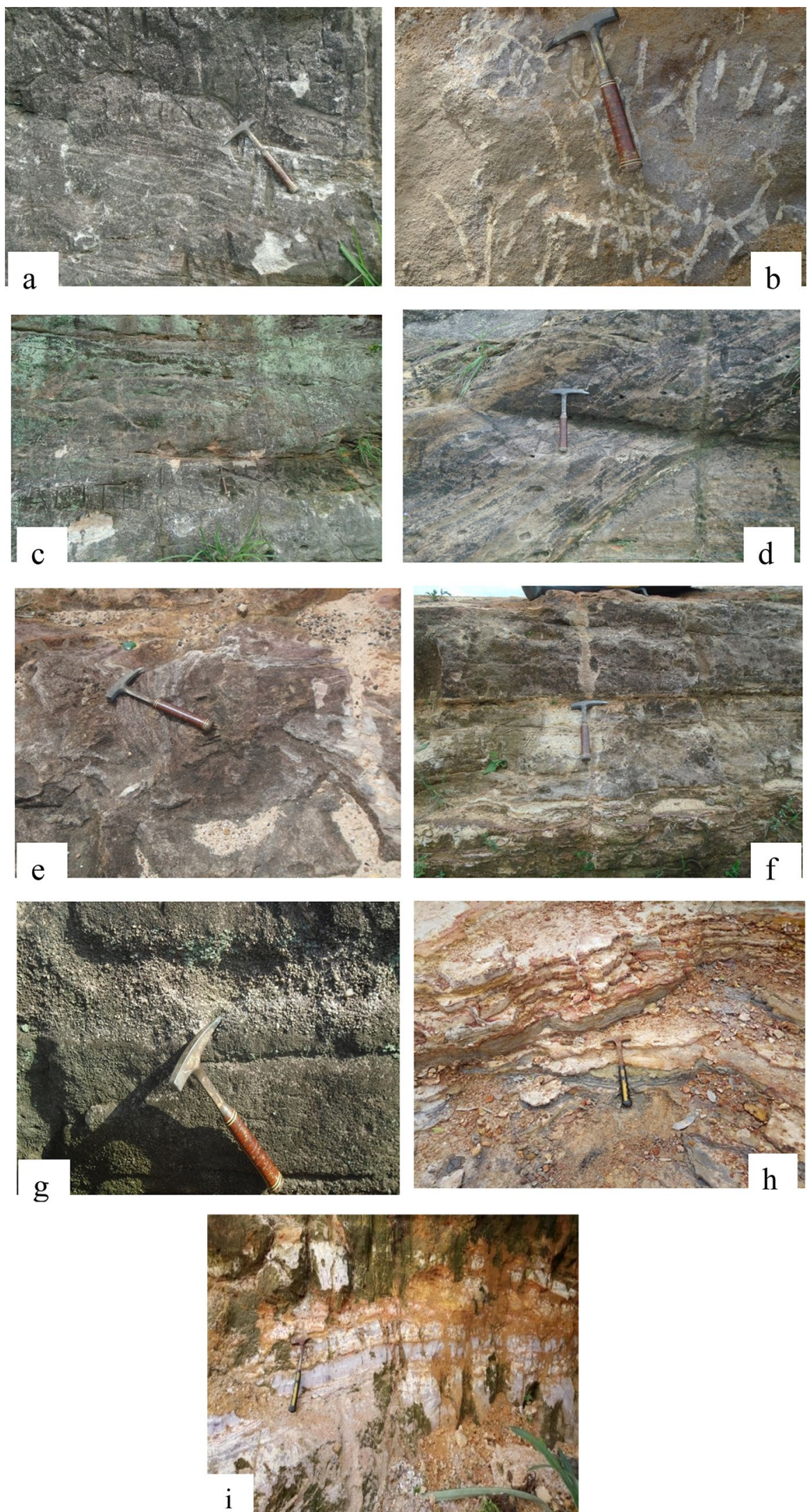
(Figs. 3 and 4): estuarine mudflat facies association (FA 1), estuarine bayhead delta facies association (FA 2), central estuarine delta facies association (FA 3) and subtidal sand ridge/foreshore facies association (FA 4). The figures show vertical profiles for the lithofacies and the associations.

\subsubsection{Facies association 1: estuarine mudflat facies association (FA 1)}

This facies association consists of laminated mudstones (Msl). The interbedded dark gray muddy shales contain plant materials and body fossils such as bivalves and gastropods and may be blocky or muddy. This facies association is interpreted as mudflat deposits in estuarine setting. Mudflat is an important sedimentary subenvironment within estuaries which facilitate deposition of fine sediments and organic materials $[20,21]$. Sediments of marine estuary accumulate large quantity of finer sediments such as mudstones and shales.

\subsubsection{Facies association 2: estuarine bayhead delta facies association (FA 2)}

This lithofacies association consists of the planar crossstratified sandstone lithofacies (Sxp), trough cross-stratified sandstone lithofacies (Sxt), parallel laminated sandstone lithofacies (Spl), bioturbated sandstone lithofacies $(\mathrm{Sfb})$ and conglomerate lithofacies (Cgx). The planar crossstratified sandstone lithofacies ( $\mathrm{Xxp}$ ) is fine-coarse grained but dominantly coarse grained with dispersed pebbles, while the trough cross-stratified sandstone lithofacies (Sxt) is generally medium to very coarse grained, poorly to moderately sorted with graded foreset laminae and quartz pebbles. The parallel laminated sandstone lithofacies (Spl) essentially displays horizontal to subhorizontal laminations. The bioturbated sandstone lithofacies $(\mathrm{Sfb})$ is generally very fine to fine grained with moderate bioturbation, while the conglomerate lithofacies (Cgx) consists of conglomerates with vein quartz pebbles. This lithofacies association is interpreted as fluvio-estuarine deposits in bayhead delta environments [22, 24].

\subsubsection{Facies association 3: central estuarine delta facies association (FA 3)}

This facies association (FA 3) comprises the sandy bioturbated heterolith (Sbh) and bioturbated cross-stratified sandstone lithofacies (Sxb). The sandy bioturbated heterolith (Sbh), which consists of very fine to grained sandstoneinterbedded with laminated mudstone and siltstone, is characterized by wavy ripple laminations, flaser beddings and occasional burrows. The bioturbated cross-stratified sandstone lithofacies (Sxb) is generally medium to coarse grained, is poorly sorted and contains planar cross-stratifications and occasional herringbone structures. This lithofacies association belongs to central estuarine delta dominated by intertidal bayfill and lagoonal muddy deposits [23].

\subsubsection{Facies association 4: subtidal sand ridge/foreshore facies association (FA 4)}

This facies association consists of planar cross-stratified sandstone lithofacies (Sxp), trough cross-stratified sandstone lithofacies (Sxt) and bioturbated cross-stratified sandstone lithofacies $(\mathrm{Sxb})$. The bioturbated cross-stratified lithofacies contains planar cross-stratifications, occasional bidirectional foreset beds (herringbone structures) and clay-draped foresets, ripples and reactivation structures. These lithofacies occur as subtidal sand ridge/foreshore environment [24-26].

\subsection{Ichnofossils}

Two ichnofacies were identified in the bioturbated sandstone and bioturbated cross-stratified sandstone lithofacies in the Afikpo Sandstone in the Macgregor Hill. The lithofacies are characterized by high abundance, intermittently distributed ichnofossil assemblages dominated by Skolithos ichnofacies and low to moderate abundance, sparsely distributed Cruziana ichnofacies. The Skolithos ichnofacies identified in the premises of the Ebonyi Hotel, Afikpo, Macgregor Hill, Ebonyi Hotel gate and the Government Secondary School Round includes the Ophiomorpha nodosa, Ophiomorpha, Skolithos and Chondrites ichnospecies (Fig. 6a-C). [27] has observed that Ophiomorpha is produced by many different organisms among which are the Callianasa, Upogebia, Axius and Thalassina. The Cruziana ichnofacies in the lithofacies occur as Planolites isp [28] and Chondrites (Figs. 5b, 6b and d). The Ophiomorpha nodosa are commonly tube-like or cylindrical in morphology, generally vertical or oblique or bifurcating (branching) in places. The ichnospecies with beaded and knobby outer wall and smooth inner structure is identified as Ophiomorpha nodosa [28-31], while the other species with tunnel of uniform diameters, vertical, smooth outerwall structure are Skolithos isp and Ophiomorpha isp. The cross-sectional diameter varies from 1.0 to $2.00 \mathrm{~cm}$, while lengths of the shafts could be up to $30 \mathrm{~cm}$ in some cases. Chondrites bollensis (Fig. 6d) occur in the bioturbated lithofacies at the Macgregor Hill as tunnels of uniform, horizontal to sub-vertical structures. Ophiomorpha and Skolithos ichnospecies (Skolithos ichnofacies) and Chondrites and Planolites ichnospecies (Cruziana ichnofacies) were identified in this study. Generally, the Afikpo Sandstone lithofacies are characterized by fair to high bioturbations, 

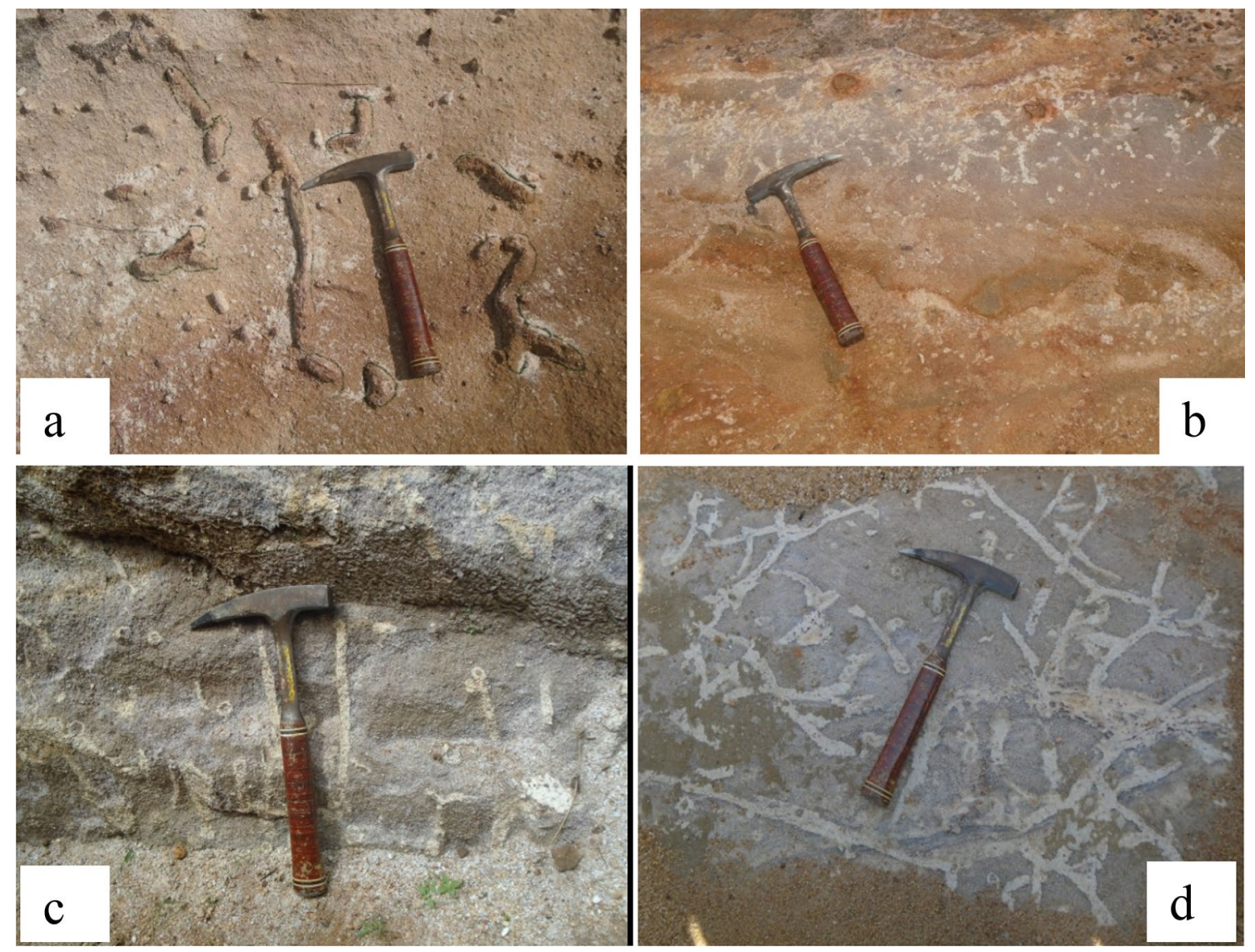

Fig. 6 Field photographs of ichnofossils in the Afikpo Sandstone a Ophiomorpha nodosa in the bioturbated sandstone lithofacies along Macgregor Hill-Amuro road, Afikpo; b Skolithos and Chondrites in the bioturbated cross-stratified sandstone lithofacies at

intermittently distributed ichnofossil assemblages belonging to Skolithos and Cruziana ichnofacies.

The Skolithos ichnofacies belongs to the dwelling (domichnia) and suspension feeders (fodinichnia) of [32]. The Cruziana ichnofacies in the area belongs to fodinichnia [33-35]. The fodinichnia (suspension feeders) are typical feeding structures representing extensive subsurface foraging by deposit-feeding organisms. They represent traces non-vagile deposits feeders [36]. The domichnia are simple tubes, shafts or integrated shaft tunnels and shafts made by endobenthic suspension feeders [27]. They represent traces developed in full oxygenated shallow waters [36].

\subsection{Petrography}

Figure $7 \mathrm{a}-\mathrm{g}$ shows the photomicrographs of sandstone samples obtained from the Afikpo Sandstone. Modal analysis showed that sandstones from the different lithofacies differ in their compositions and textures. Sandstone samples of the planar cross-stratified lithofacies (Sxp) contain approximately $54 \%$ quartz, $5.50 \%$ weathered
Macgregor Hill; c Ophiomorpha nodosa and Skolithos in the bioturbated cross-stratified sandstone lithofacies opposite Ebonyi Hotel, Afikpo; $\mathbf{d}$ Chondrites bollensis in the bioturbated sandstone lithofacies along Ozizza road, Afikpo

feldspar, matrix content of $16 \%, 10 \%$ of clay patches and iron oxide cement, and void (porosity) volume of $14.50 \%$. This lithofacies is fine to coarse $(0.10-0.45 \mathrm{~mm})$ but dominantly medium $(0.31 \mathrm{~mm})$ and poorly sorted. The fabric is matrix supported with the framework grains floating in clay matrix. Accordion-like kaolinitic plates coat some of the grains, while unrecrystallized clay patches occupy some intergranular voids.

The trough cross-stratified lithofacies (Sxt) and bioturbated cross-stratified sandstone (Sxb) lithofacies from some outcrop sections along the Macgregor Hill consist of fine- to coarse-/very coarse-grained sandstone $(0.15-1.50 \mathrm{~mm})$ but dominantly coarse with mean size of $1.02 \mathrm{~mm}$ and moderately to very poorly sorted (Fig. $5 \mathrm{c}$ and d).

The modal analysis of the bioturbated cross-stratified sandstone lithofacies (Sxb) showed average composition $71.73 \%$ quartz, $8.13 \%$ weathered feldspar $2.59 \%$ rock fragment, $7.01 \%$ matrix, $1.27 \%$ cement and $9.27 \%$ void space (porosity). The sandstone is medium to coarse grained varying in size from 0.21 to $1.00 \mathrm{~mm}$, with clay 

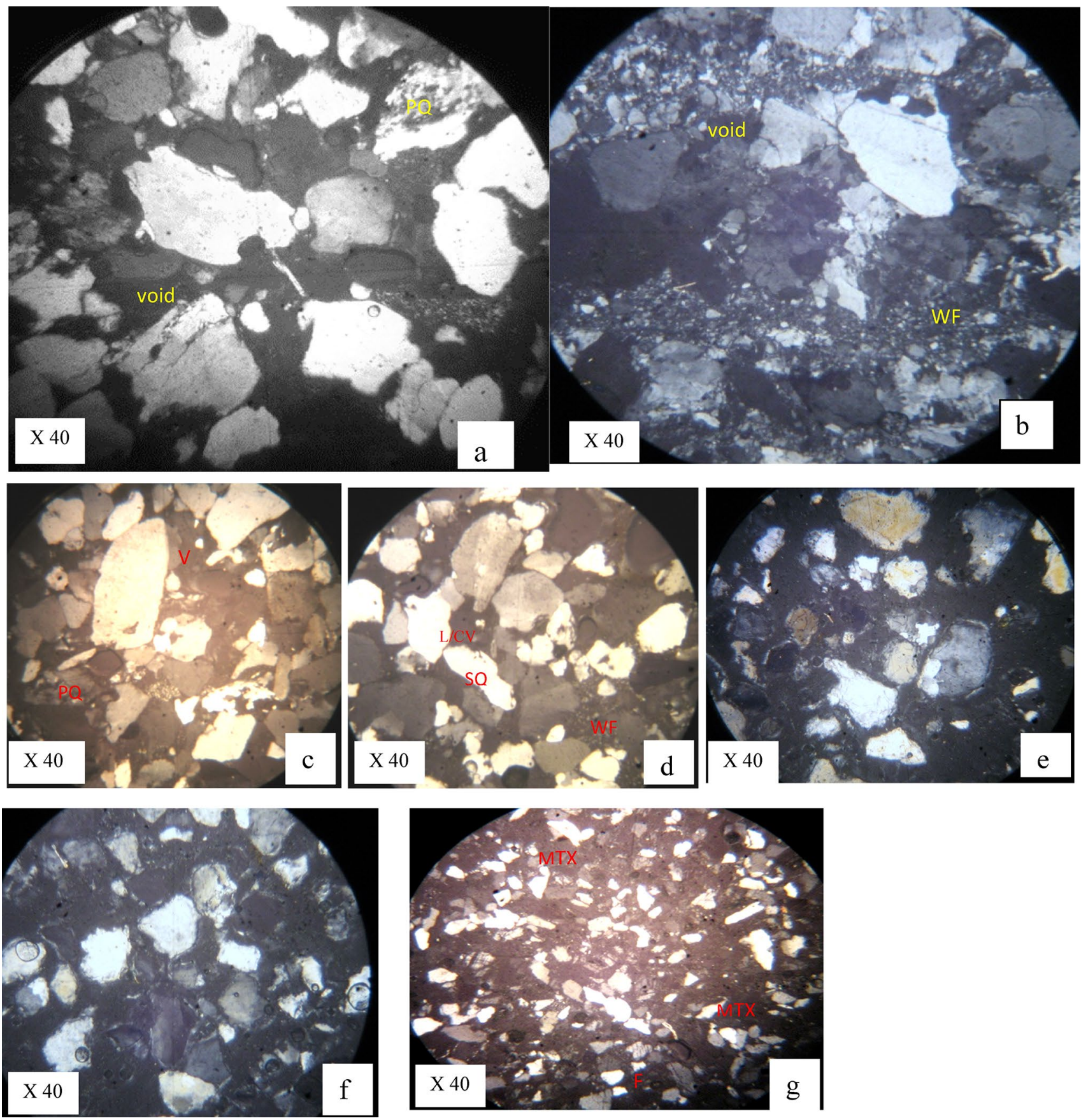

Fig. 7 Photomicrographs of sandstone samples obtained from Afikpo Sandstone (a and $\mathbf{b})$. Trough cross-stratified sandstone lithofacies (Sxt) a showing polycrystalline grain (PQ) and weathered feldspar (WF); b polymodal grain-size distribution with alternating laminations of fine and coarse bands; (c and d) Planar cross-stratified sandstone lithofacies (Spl) c showing line and concavo-convex contacts (L/CV), polycrystalline quartz (PQ) and weathered feldspar $(\mathrm{WF})$, void space (V) d strained, elongated quartz (SQ) \& weathered

matrix as cement, and moderately sorted with angular to subrounded grains. The monocrystalline quartz grains are elongate shapes, often with micro-fractures and inclusion feldspar (WF) grains in a framework-supported fabric unrecrystallized clay matrix and iron oxide cement constitute the void fillers; (e and f) bioturbated cross-stratified sandstone lithofacies (sxb) with clay matrix supported framework and iron oxide cement. Sandstone has angular to subangular grains in a matrix of clay and patchy iron oxide cement occurs in $\mathbf{f} ; \mathbf{g}$ parallel laminated sandstone lithofacies with abundant clay matrix and grains are angular to subangular in a matrix of clay

trains, and show strong to wavy undulosity. The polycrystalline grains in the trough cross-stratified sandstone samples are stretched and elongated with crenulated

\section{SN Applied Sciences}


and often sutured subgrain contacts (Fig. 7a). The fabric is often framework supported with line and concavo-convex contacts. The void fillers consist generally of brownish patches of clay matrix and iron oxide which weakly bind the grains together, acting as incompatible cement.

Modal analysis of parallel laminated sandstone lithofacies indicates $60.4 \%$ quartz, $5.00 \%$ weathered feldspar, $1.0 \%$ rock fragment, $20.35 \%$ clay matrix and iron oxide cement, and void space $13.25 \%$ (porosity). The void filling materials are clay matrix and iron oxide both of which serve as very weak binder. The sandstones vary in grain size from 0.065 to $0.20 \mathrm{~mm}$ with an average of $0.10 \mathrm{~mm}$. The grains are mainly monocrystalline, subangular to subrounded and moderately to poorly sorted (Fig. $7 \mathrm{~g}$ ). The fabric is matrix supported. Generally, the Afikpo Sandstone in the study area consists of mainly quartz and subordinate weathered feldspar and metamorphic rock fragments as framework elements. The grains are angular to subangular and equant, often with inclusions and fractures. The polycrystalline grains contain more than five subgrains in most cases. The fabric is framework supported with line and concavo-convex grain contacts. Feldspars occur as seriously weathered discrete grains with well-defined contacts which may be misinterpreted as matrix. The cementing agent is iron oxide, occurring as yellowish-brown irregular bands flowing between the grains.

\subsection{Textural analysis}

Table 3 shows the univariate grain-size parameters from textural data. Table 4 shows the paleoenvironmental interpretation based on [15] univariate parameters of mean, standard deviation (sorting), skewness and kurtosis. The overall environment suggested by environmentally sensitive parameters of standard deviation, and skewness may vary from continental (fluvial) to marine (shallow shelf) setting. Table 5 shows the result of paleoenvironmental interpretation using multivariate discriminant functions [37]. The discriminant functions based on the entire textural parameters of mean, standard deviation skewness

Table 3 Calculated inclusive graphic measure from samples of Afikpo Sandstone

\begin{tabular}{|c|c|c|c|c|}
\hline $\begin{array}{l}\text { Sample } \\
\text { no }\end{array}$ & $\begin{array}{l}\text { Inclusive graphic } \\
\text { mean }(\mathrm{Mz}) \\
(\Phi)\end{array}$ & $\begin{array}{l}\text { Inclusive graphic standard } \\
\text { deviation }(\Phi)\end{array}$ & $\begin{array}{l}\text { Inclusive graphic skewness (Sk) } \\
(\Phi)\end{array}$ & $\begin{array}{l}\text { Inclusive graphic kurtosis (Kg) } \\
(\Phi)\end{array}$ \\
\hline UA01 & 0.10 (fine sand) & 1.14 (poorly sorted) & 0.66 (very positively skewed) & 1.08 (mesokurtic) \\
\hline UA02 & 0.58 (coarse sand) & 1.27 (poorly sorted) & 0.64 (very positively skewed) & 2.93 (very leptokurtic) \\
\hline UA03 & 0.58 (coarse sand) & 1.15 (poorly sorted) & 0.57 (very positively skewed) & 1.13 (leptokurtic) \\
\hline UA04 & 0.56 (coarse sand) & 1.18 (poorly sorted) & 0.58 (very positively skewed) & 1.19 (leptokurtic) \\
\hline UA05 & 0.30 (medium sand) & 0.81 (moderately sorted) & 0.68 (very positively skewed) & 2.52 (very leptokurtic) \\
\hline UA06 & 0.38 (medium sand) & 0.96 (moderately sorted)) & 0.59 (very positively skewed) & 1.19 (leptokurtic) \\
\hline UA07 & 0.38 (medium sand) & 0.93 (moderately sorted) & 0.63 (very positively skewed) & 1.23 (leptokurtic) \\
\hline UA08 & 0.35 (medium sand) & 0.98 (moderately sorted) & 0.57(very positively skewed) & 1.56 (very leptokurtic) \\
\hline UA09 & 0.40 (medium sand) & 0.80 (moderately sorted) & 0.44 (very positively skewed) & 1.15 (leptokurtic) \\
\hline UA10 & 0.38 (medium sand) & 0.93 (moderately sorted) & 0.63 (very positively skewed) & 1.48 (leptokurtic) \\
\hline UA11 & 0.45 (medium sand) & 0.98 (moderately sorted) & 0.63 (very positively skewed) & 1.42 (leptokurtic) \\
\hline Average & 0.41 (medium) & 1.01 (poorly sorted) & 0.60 (positive skew) & \\
\hline
\end{tabular}

Table 4 Summary of the geological significance of the parameters

\begin{tabular}{|c|c|c|}
\hline Parameters & Exhibited characteristics & Environmental indication \\
\hline Mean & $\begin{array}{l}\text { Range from } 0.30 \text { to } 0.58(\Phi) \text { with mean value of av. } \\
0.41(\Phi) \text { with } 5 \% \text { very fine-fine grains, } 35 \% \text { coarse grain } \\
\text { and } 60 \% \text { medium grain }\end{array}$ & $\begin{array}{l}\text { Not diagnostic of environment but reflects the overall } \\
\text { grain size }\end{array}$ \\
\hline Standard deviation & $\begin{array}{l}\text { Ranges from } 0.98 \text { to } 1.14(\Phi) \text { with mean } .1 .01(\Phi), 60 \% \\
\text { moderately sorted and } 40 \% \text { poorly sorted }\end{array}$ & $\begin{array}{l}\text { Indicates deposits in marginal marine environment with } \\
\text { moderate energy (Folk and Ward 1958) }\end{array}$ \\
\hline Skewness & $\begin{array}{l}\text { Ranges from } 0.44 \text { to } 0.68 \Phi \text { with the average value of } 0.60 \\
(\Phi) \text {; very positively skewed }\end{array}$ & $\begin{array}{l}\text { Indicates fluvial (river) environment (Moiola and Weiser, } \\
\text { 1968) }\end{array}$ \\
\hline Kurtosis & $\begin{array}{l}\text { Ranges from } 1.13 \text { to } 2.93(\Phi) \text { with the average value of } \\
1.53(\Phi) \text {. About } 5 \% \text { mesokurtic, } 60 \% \text { leptokurtic and } \\
35 \% \text { very leptokurtic }\end{array}$ & Not sensitive in environment analysis (Folk and Ward 1957) \\
\hline
\end{tabular}


Table 5 Discriminate function and interpretation of paleoenvironments

\begin{tabular}{llllll}
\hline Y1 & $\begin{array}{l}\text { Depositional envi- } \\
\text { ronment }\end{array}$ & Y2 & Depositional environment & Y3 & Depositional environment \\
\hline 2.7187 & Aeolian & 7008.5404 & Shallow agitated marine & -2.3399 & Shallow shelf environment \\
1.1098 & Aeolian & 6574.09012 & Shallow agitated marine & -3.2884 & \\
4.1716 & Beach & 7128.81374 & Shallow agitated marine & -2.4146 & \\
0.8711 & Aeolian & 8149.8549 & Shallow agitated marine & -3.77814 & -2.33504 \\
3.03005 & Beach & 4446.166078 & Beach & -2.2145 \\
4.5349 & Beach & $15,640.00602$ & Beach & -1.7938 \\
3.4453 & Beach & 6158.688194 & Beach & -2.5168 \\
3.8499 & Beach & 3862.892493 & Beach & -3.1375 \\
4.5763 & Beach & 5671.082095 & Beach & -2.5225 \\
3.4763 & Beach & 5858.573543 & Beach & -3.0977 \\
4.0054 & Beach & 5967.383623 & Beach & \\
\hline
\end{tabular}

Table 6 Evaluation of porosity and permeability of Afikpo Sandstone unit using empirical equation of [16] and [17]

\begin{tabular}{llllll}
\hline $\begin{array}{l}\text { Sample } \\
\text { no }\end{array}$ & $d_{10}$ & $d_{60}$ & $\begin{array}{l}\text { Coefficient of } \\
\text { uniformity }(\mathrm{u})\end{array}$ & Porosity & $\begin{array}{l}\text { Permeability } \\
\text { millidarcies }(\mathrm{md})\end{array}$ \\
\hline UA01 & 1.4 & 0.4 & 0.28 & 0.487 & $32.65 \mathrm{md}$ \\
UA02 & 2.6 & 0.6 & 0.23 & 0.499 & $112.6 \mathrm{md}$ \\
UA03 & 1.3 & 0.71 & 0.55 & 0.485 & $28.15 \mathrm{md}$ \\
UA04 & 1.6 & 0.58 & 0.36 & 0.493 & $42.64 \mathrm{md}$ \\
UA05 & 1.4 & 0.74 & 0.53 & 0.486 & $32.65 \mathrm{md}$ \\
UA06 & 1.35 & 0.68 & 0.50 & 0.487 & $30.32 \mathrm{md}$ \\
UA07 & 1.25 & 0.39 & 0.31 & 0.496 & $26.03 \mathrm{md}$ \\
UA08 & 1.55 & 0.72 & 0.46 & 0.489 & $40.02 \mathrm{md}$ \\
UA09 & 1.4 & 0.73 & 0.52 & 0.486 & $32.65 \mathrm{md}$ \\
UA10 & 1.3 & 0.52 & 0.4 & 0.492 & $28.15 \mathrm{md}$ \\
UA11 & 1.4 & 0.75 & 0.54 & 0.486 & $32.65 \mathrm{md}$ \\
\hline
\end{tabular}

and kurtosis suggest that the sediments were deposited in shallow shelf environment.

\subsection{Evaluation of sandstone reservoir parameters of the Afikpo Sandstone}

The results of evaluation of sandstone reservoir parameters are shown in Table 6, and plots of grain-size frequency distribution using cumulative weight percent versus grain size in millimeters $(\mathrm{mm})$ were used to determine grain-size diameter at 10 and 60 percentiles $\left(d_{10}\right.$ and $\left.d_{60}\right)$ (see supplementary data, $\mathrm{L}-\mathrm{U}$ ) for the sieved samples. The relevant reservoir parameters are mainly porosity and permeability. These reservoir parameters were calculated using Eqs. 1 and 2 and are presented in Table 6 . The porosity ranges from 0.485 to 0.499 with the average value of 0.49 , while permeability ranges from 26.03 to 42.64 with the average value of $39.86 \mathrm{md}$. This suggests that the Afikpo Sandstone is good potential reservoir for hydrocarbon accumulation.

\section{Discussion}

\subsection{Paleoenvironments}

The lithofacies and textural analyses and ichnofossils have provided insights on the paleoenvironments for the Afikpo Sandstone. Lithofacies analysis provides an understanding of the depositional environments, and paleogeography existing at the time a rock unit was deposited $[19,25,26]$. Ichnofossil assemblages of the Skolithos-Cruziana-Zoophycos-Nereites can be useful in the reconstruction of shallow-deep water depositional settings [38-40]. [40] noted that vertical burrows are found in shallower water, while horizontal and patterned burrows occur in deeper water. The Afikpo Sandstone facies recorded ichnofossils of Skolithos-Cruziana ichnofacies (shallow water ichnofacies) (Fig. 6). However, there is dominance of sub-vertical and vertical burrows (Skolithos ichnofacies) over horizontal burrows (Cruziana ichnofacies), indicating moderate- to high-energy environmental conditions.

However, bathymetry is not the control factor in determining ichnofacies because shallow and marginal marine ichnofacies have been registered in deeper marine settings [41], hence the combination of lithofacies/facies association, textural analysis and ichnofossils. The emphasis is more on the reliability of lithofacies $[19,25,26]$. Based on the lithofacies analysis, the estuarine lithofacies associations represent mudflat deposits in estuary setting [20, 21, 42], a fluvio-estuarine sandstones in bayhead delta environments [22-24] and central estuarine dominated by intertidal bayfill and lagoonal muddy deposits.[23]. The foreshore lithofacies association represents subtidal sand 
ridge in the foreshore setting. The planar cross-stratified and trough cross-stratified sandstone lithofacies are characteristics of estuarine channels and point bars $[43,44]$ in estuarine setting. The presence of herringbone and reactivation structures supports this interpretation. More so, the occurrence of these sedimentary features alongside herringbone structures and widespread occurrence of Skolithos ichnofacies burrows in the bioturbated sandstone facies of the Afikpo Sandstone supports tidal/fluvial estuarine point bars in bayhead delta for the cross-stratified (planar and trough) and bioturbated sandstone lithofacies $[22-24,43,44]$. The parallel laminations in the mudstones and the interbedding dark gray, fossiliferous muddy shales indicate estuarine mudflat environment $[20,21]$.

The textural characteristics of the Afikpo Sandstone indicate that the sandstones vary from medium to coarse grained, which suggests that the sediments were deposited by river system [45]. The poor sorting showed the sandstones were deposited under a wide range of current velocities and turbulence, which resulted in deposition of variable and sand-sized sediments in the study area [46, 47]. [48] regarded such poorly sorted sandstones as deposits of river environment. The skewness of the sandstones indicate very positively skewed (Table 3 ). This indicates deposition in a relatively moderate to high fluvial energy environment $[45,48]$. On the basis of the interpretations from textural analysis, fluvial to marine (fluvio-marine) was deduced as the paleoenvironment of deposition for the sandstones. However, this interpretation is "very coarse" because texture alone does not have the ability to resolve all the dynamic effects of physical, biological and chemical activities prevalent in a geomorphic environment. It does not recognize channels; neither can it recognize bars nor any geomorphic entity. [17, 49,50] and [51] recognized this challenge earlier and played down on research and application of textural analysis for paleoenvironmental analysis. Therefore, it should be applied with caution in paleoenvironmental interpretation.

The Afikpo Sandstone (Campanian) recorded Skolithos-Cruziana ichnogenera (shallow water ichnofacies). There is higher abundance of sub-vertical and vertical burrows (Skolithos ichnofacies) than horizontal burrows (Cruziana ichnofacies), suggesting predominance of high-energy environment in the area. Skolithos ichnofacies is typical of areas subjected to high sedimentation influx [52-54]. The presence of this burrow type indicates high-energy shallow shelf environmental setting $[26,55,56]$. The absence of deep water ichnofacies (Zoophycos-Nereites) in the area indicates that the Campanian epeiric sea was shallow. The interpretations of paleoenvironments deduced from study from lithofacies and textural analysis as ichnofossil assemblages are contemporaneous. However, based on the lithofacies/ associations, fluvio-estuarine and shallow shelf (foreshore) to shoreface paleoenvironmental setting is generally suggested for the Afikpo Sandstone. This represents a finer resolution of the depositional environments and identifies geomorphic entities than textural analysis.

\subsection{Reservoir quality}

Depositional environmental setting is a key to identifying potential reservoir rocks capable of storing and transmitting fluids, such as hydrocarbons and water. The depositional dynamics and energy of the environment control reservoir properties of the rocks such as the porosity and permeability. It is generally believed that porosity is largely controlled by sorting, compaction and cementation, while permeability is controlled by size and shape of the grains. Other controlling factors on permeability include the amount of fines (silts and clay), presence of cements and fractures. Permeability is governed by the size of the pores; the larger the pore sizes, the higher the permeability. To be permeable, the sandstone must have interconnected pore space (intergranular porosity), interconnected vugs or fractures. The mean porosity of $0.48(48.00 \%)$ for sandstones of the studied section based on sieve data is extremely overestimated and unrealistic compared with mean $12.34 \%$ got from petrographic analysis. This is understandable since all the fines (cement and matrix) which reduced the primary porosity have been removed and do not contribute to the empirical formula used for the porosity estimate [16]. Moreover, the effect of compaction (elongation of grains, line and concavo-convex contacts) noted during petrographic analysis was also removed in the empirical porosity evaluation. [57] noted that porosity of recently deposited and unconsolidated sandstone not exceeds $48 \%$. Therefore, porosity of late Campanian Afikpo Sandstone, after diagenesis (compaction and cementation) and addition of clay due to decay of feldspars should be much less than $48 \%$. Porosities of $9.27-14.50 \%$ recorded from petrographic modal analysis seem to be more acceptable.

Permeability is the property of rock which allows appreciable quantity of fluid to flow through a volume of rock without impairment of its structures $[26,57]$. The obvious impediments to permeability are cements and matrix which obscure pore connectivity by reducing pore throats and inter-particle pores. The empirical permeability of 26.03-42.64 millidarcies with the average value of 39.86 millidarcies classifies the reservoirs as good [58] and is capable of storing and transmitting fluids such as hydrocarbons and water. This suggests that the Afikpo Sandstone could serve as a potential hydrocarbon reservoir in the Afikpo Sub-basin. 


\section{Conclusion}

This study has interpreted the paleoenvironment of deposition of the exposed section of Afikpo Sandstone using lithofacies characteristics, textural analysis and ichnofossils. Also, the study evaluated two major reservoir properties of sandstone to ascertain its potential to store hydrocarbon or other fluids using empirical equations and sieve analysis parameters and petrography. Paleoenvironmental interpretation by sieve data indicated a fluvio-marine environment which is ambiguous compared to interpretation by lithofacies analysis which refined the fluvio-marine realm into four specific geomorphic subenvironments or lithofacies associations, namely lower shoreface facies association (FA 1), estuarine bayhead delta facies association (FA 2), central estuarine delta facies association (FA 3) and subtidal sand ridge/foreshore facies association (FA 4). It is therefore concluded that paleoenvironmental interpretation by lithofacies analysis using at least five lithofacies parameters is more credible and gives a better and more reliable interpretation than textural data from sieve analysis.

Reservoir property evaluation results using sieve data and empirical equations for the Macgregor Hill outcrops of Afikpo Sandstone showed that the sandstone has good potential as hydrocarbon reservoirs with mean porosity of $48 \%$ and mean permeability of 39.86 millidarcies. However, the porosity of the rocks was grossly overestimated due to friable and unconsolidated nature of the rocks and elimination of fines (clay and silts) during the sieving. A fairly good mean porosity estimates of 12. 34\% from petrography was due to diagenetic effect of clay/silt matrix and iron oxide cement still intact during analysis. It is concluded that petrography is a better option in porosity evaluation than empirical equations.

\section{Compliance with ethical standards}

Conflict of interest No conflict of interest was reported by the authors.

\section{References}

1. Nwajide CS (2013) Geology of Nigeria sedimentary basins. CSS Bookshops Limited, Lagos, p 565

2. Akande SO, Ogunmoyero IB, Petersen HL, Nyloft HP (2007) Source rock evaluation of coal from the lower Maastrichtian Mamu Formation, southeastern Nigeria. Petro Geol J 30:303-324

3. Reyment RA (1965) Aspects of the Geology of Nigeria: the stratigraphy of the Cretaceous and Cenozoic deposits. University of Ibadan Press, Ibadan, p 145
4. Simpson A (1954) The Nigerian coal field: the geology of parts of Onitsha, Owerri and Benue provinces. Geol Surv Nig Bull 24:67

5. Petters SW, Edet A (1996) Interpretation of Nkporo Formation as shallow marine and brackish water basal on fossil and Palynological biostratigraphic data from shale lithofacies. J Geol Min 27:205-211

6. Okoro AU, Onuigbo EN, Akpunonu EA, Obiadi II (2012) Lithofacies and pebbles morphogenesis: key to paleoenvironmental interpretation of Nkporo Formation, Afikpo sub-Basin. Nigeria J Environ Earth Sci 2:26-38

7. Ndefo D, Aduroja B, Unachukwu O, Allix P, Caileaux P, Grugnola MT (1987) Anambra Basin: A synthetic review of exploration activities. Elf Nigeria 1:1-68

8. Teoh YJ (2007) Characteristics of sedimentary facies and reservoir properties of some tertiary sandstones in Sabah and Sarawak, East Malaysia. Unpublished M.Sc., thesis,) school of Physics, University of Sains, Malaysia. J. American Sci. and Industrial Res. 4:119.

9. Okoro AU, Igwe EO (2018) Lithostratigraphic characterization of the upper Campanian -Maastrichtian, succession in the Afikpo Sub-basin, southern Anambra Basin. Nigeria J Afri Earth Sci 147:178-189

10. Murat RC (1972) Stratigraphy and paleogeography of the Cretaceous and lower Tertiary in Southern Nigeria. In: Geology A (ed) TFJ Dessauvagie, AJ, Whiteman. University of Ibadan, Nigeria, pp 201-266

11. Obi GC (2000) Depositional model for the Campanian-Maastrichtian Anambra Basin, southeastern Nigeria. (unpublished Ph.D thesis), Department of Geology, University of Nigeria, Nsukka, p 286.

12. Gazzi P (1996) Le arenarie del Flysch sopracretaceo dell Appennino modenese; correlazioni conil Flysch di monghidoro. Mineral et petrogr Acta 12:69-97

13. Dickinson WR (1970) Interpreting detrital modes of greywacke and arkose. J Sediment Petrol 40:695-707

14. Blatt H (1992) Sedimentary Petrology. Freeman, New York, p 514

15. Folk RL, Ward WC (1957) An interpretation of trend in grain size descriptive analysis of sandstone measures. J Sediment Petrol 37:232-334

16. Hazen A (1982) The reservoir parameters assessment on porosity and permeability of sandstone and its classification range evaluation. J Sediment Geol 36:107-192

17. Krumbein WC, Monk GD (1945) Reservoir parameters evaluations classification range and interpretation. Niger Assoc Petrol Explor 29:81-101

18. Sahu BK (1964) Depositional mechanisms form the size analysis of clastic sediments. J sediment Petrol 34:73-83

19. Walker RG (1984) Shelf and shallow marine sands, Facies models. Geosci Can Reprint Ser 1:141-170

20. Turner S, Riddle B (2001) Estuarine sedimentation and vegetation-management issues and monitoring priorities. Environment Waikato Internal Series 2001/05. Document \#: 686944.

21. Nayak GN (2018) Noronha e D'Mello CA (2018) Estuarine mudflat and mangrove sedimentary environments along Central West Coast of India. SF J Environ Earth Sci 1(1):1013

22. Allen GP (1991) Sedimentary processes and facies in the Gironde estuary: a recent model for macrotidal estuary system. In: Smith DG, Reinson GE, Zaitlin BA, Rahmani RA (eds) Clastic tidal sedimentology Memoir. Canadian Society of Petroleum Geologists, Calgary, pp 25-36

23. Dalrymple RW, Zaitlin BA, Boyd RI (1992) Estuarine facies models: conceptual basis and stratigraphic implications. J Sediment Petrol 62:1130-1146

24. Shanmugam G, Poffenberger M, Toro Alava J (2000) Tidedominated estuarine facies in the Hollin and Napo (' $T$ ' and ' $U$ ') 
formations (Cretaceous), Sacha Field, Oriente Basin, Ecuador. Am Asso Petrol Geol Bull 84:652-682

25. Miall AD (2000) Principles of sedimentary Basin Analysis, vol 3. Springer, Berlin, p 616

26. Nichols G (2009) Sedimentology and stratigraphy, vol 2. WileyBlackwell Publication, Hoboken, p 419

27. Frey RW (1978) Behavioral and ecological implications of trace fossils. In: Basan PB (ed) Trace fossil concepts. Miscellanea University of Kansas Press, Kansas, pp 177-245

28. Mode AW (1993) Ethology and paleoenvironmental significance of trace fossils from Cenomanian-Turonian sediments in the upper Benue Trough. Nigeria J Min Geol 29:102-109

29. Hoque M, Nwajide CS (1979) A lithostratigraphic analysis of the Nanka Sands, southeastern Nigeria. Niger J Min Geol 16:103-109

30. Mbuk IN, Rao VI, Kumaran KPN (1985) The upper CretaceousPaleocene boundary in the Ohafia-Ozu Abam area, Imo State. J Min Geol 22:105-109

31. Anyanwu RPC, Arua I (1990) Ichnofossils from Imo Formation and their paleoenvironmental significance. J Min Geol 26:1-4

32. Eckdale AA, Bromley RG, Pemberton SG (1984) Shallow marine terrigenous environments. In Ichnology. Trace fossils in Sedimentology and Stratigraphy. SEPM Short Course 15:185-198

33. Frey RW, Howard JD (1970) Comparison of Upper Cretaceous ichnofaunas from siliceous sandstones and chalk, Western Interior Region, USA. In: Crimes TP, Harper JC (eds) trace fossils. Seel House Press, Liverpool, pp 141-166

34. Permberton SG, Frey RW (1982) Trace fossil nomenclature and the Planolites-Paleophycus dilemma. J Paleontol 56:843-881

35. Permberton SG, Frey RW (1984) Ichnology of storm influenced shallow marine sequence, Cardium Formation (Upper Cretaceous) at Seebe, Alberta. In: Stolt DF, Glass DJ (eds) The Mesozoic of middle North America. CSPG special publications, Canada, pp 281-304

36. Bromley RG (1996) Trace fossils: biology, taphonomy and application. Chapman and Hall, London, p 361

37. Sahu BK (1964) Depositional setting of sediments in grain size feasibility. Applied univariate, bivariate and Multivariate scatter analysis discriminate function of $\left(Y_{1} Y_{2} Y_{3}\right)$ : grain size analysis and depositional environment for beach sediment along Abu Dhabi Coast, United Arab Emirate. Intl J of Sci Tech Res 5:106-113

38. Seilacher A (1963) Lebensspuren and salinitatsfazies. Fortschrrite Geologic Von Rheinland uber westfalen 10:81-94

39. Seilacher A (1964) Sedimentological classification and nomenclature of trace fossils. Sedimentology 3:253-256

40. Seilacher A (1967) Bathymetry of trace fossils. Mar Geol 5:413-428

41. Frey RW, Howard JD, Pryor WA (1978) Ophiomorpha: its morphologic, taxonomic, and environmental significance. Palaeogeogr Palaeoclimatol Palaeoecol 23:199-229

42. Stutz ML, Pilkey OH (2002) Global distribution and morphology of deltaic barrier island systems. J Coastal Res 36:694-707

43. Elliot T (1986) Deltas. In: Reading HG (ed) Sedimentary environment and facies. Blackwell, Oxford, pp 113-154
44. Miall AD (1984) Deltas. In: Walker RG (ed) Facies models. Geological Association of Canada, Geosciences Canada Reprint Series 1. pp 105-118

45. Friedman GM, Sanders JE (1978) Principles of sedimentology. Wiley, New York, p 792

46. Amarol EJ, Pryor WA (1977) Depositional environment of St. Peter sandstone deduce by textual analysis. J Sediment Petrol 40:32-55

47. Miall AD (1992) Alluvial deposits Facies models: response to sea level changes. Geol Assoc Canada 71(4):119-142

48. Friedman GM (1961) Distinction between dune, beach and river sands from their textural characteristics. J Sediment Petrol 31:514-529

49. Friedman GM (1967) Dynamic processes and statistical parameters compared for size frequency distribution of Beach and River sands. J Sed Petrol 37:327-354

50. Friedman GM (1979) Differences in size distribution of populations of particles among sands of various origins. Sedimentology 26:3-32

51. Moiola RJ, Weiser D (1977) Textural parameters: an Evaluation. J Sed Petrol 38:45-53

52. Zonneveld JP, Gingras MK, Pemberton SG (2001) Trace fossil assemblages in a Middle Triassic mixed siliciclastic-carbonate marginal marine depositional system, British Columbia. Paleogeogr Paleoclimatol Paleoecol 166:249-276

53. Savary BD, Gaillard C (2004) Claciturbidite dynamics and endobenthic colonization: example from late Barremian (Early Cretaceous) succession in southeastern France. Paleogeogr Paleoclimatol Paleoecol 211:221-239

54. Mapals JA, Gawthrorpe RL, Pollard JE, Sharp IR (2005) Ichnofabric analysis of the shallow marine Nukhut Formation (Miocene), Suez Rift Egypt, implications for depositional processes and sequence stratigraphic evolution. Paleogeogr Paleoclimatol Paleoecol 215:239-264

55. Catuneanu O (2006) Principles of sequence stratigraphy. Elsevier BV, Amsterdam, Netherlands, p 375

56. Pemberton SG, Maceachern JA (2005) Significance of trace fossils to applied stratigraphy. In: Koutsoukos EAM (ed) Applied stratigraphy. Springer, Netherlands, pp 279-300

57. Pettijohn FJ (1975) Sedimentary rocks, vol 3. Harper and Row, New York, p 628

58. Todd DK (1960) Groundwater hydrology. Wiley, New York

59. Okoro AU, Igwe EO (2014) Lithofacies and depositional environment of the Amasiri Sandstone, southern Benue Trough. Nigeria J Afri Ear Sci 100:179-190

Publisher's Note Springer Nature remains neutral with regard to jurisdictional claims in published maps and institutional affiliations. 